\title{
Dietary Habits and Nutritional Knowledge among Primary School Children in Fayoum Governorate
}

\author{
Rabab Gad Abd El-Kader ${ }^{1}$, Hanem Awad Mekhamier² \& Azza El-Sayed Ali Hegazy ${ }^{3}$ \\ ${ }^{1}$ Community Health Nursing, RAK College of Nursing, RAK Medical and Health Sciences University, Egypt \\ ${ }^{2}$ Community Health Nursing, Fayoum University, Fayoum, Egypt \\ ${ }^{3}$ Pediatric Nursing, Fayoum University, Fayoum, Egypt \\ Correspondence: Rabab Gad Abd El-Kader, Community Health Nursing, RAK College of Nursing, RAK \\ Medical and Health Sciences University, Fayoum, Egypt. E-mail: dr_rabab3@yahoo.com
}

Received: May 13, 2019

doi:10.20849/ijsn.v4i2.593
Accepted: June 4, 2019

Online Published: June 11, 2019

URL: https://doi.org/10.20849/ijsn.v4i2.593

\begin{abstract}
Background and aim: Improving the eating habits of children is essential to reduce the future burden of non-communicable illnesses. Nutritional diseases affect higher than $30 \%$ of school age children. This study aimed to assess the dietary habits and nutritional knowledge among primary school age children in Fayoum Governorate, Egypt.

Study design: A cross-sectional descriptive design was utilized. Setting: The study was implemented in three governmental mixed primary schools in EL-Fayoum city; Egypt, that were selected randomly. Sample: Cluster random sample techniques used for selecting of the study group consisted of 300 students aged from 10-12 years for both sexes attending grade five and six. Tools: three tools of data collection consisted of: 1- self-administered questionnaire comprised socio-demographic data of the students and parents, and students' knowledge about nutrition, 2- the students' dietary habits as consumption of the breakfast, drinking water, 3- Health assessment sheet to assess the students' nutritional status including weight, height, BMI, and appearance.

The study findings revealed that $69.3 \%$ of the study group were underweight, $36.3 \%$ were stunted, and $6.7 \%, 3.3 \%$ were overweight and obese respectively. About $45 \%$ had fair knowledge while $34 \%$ had good knowledge about the nutrition. More than half of the students had unhealthy dietary behavior and appearance. There was a statistically significant difference $(\mathrm{P}: 0<0.00)$ between the academic performance of the school children and their HAZ while there was no statistically significant difference between the academic performance of the students and their WAZ (P: 0.264).

Conclusions: underweight is highly prevalent among the primary school students followed by stunting. Most of the students had unhealthy dietary habits and unhealthy appearance while around half of them had fair knowledge about nutrition. The current study recommended developing a nutritional health program for primary school children about the proper nutrition.
\end{abstract}

Keywords: dietary, habits, nutritional, knowledge, primary school, children

\section{Introduction}

Children and teenagers are the most vulnerable group to the effect of inadequate nutrition. Diet is one of the factors that affects the proper development and growth of young age and maintaining good health to older age (Sitko, Wojtaś and Gronowska-Senger., 2012).

School-age children are a group characterized by the intense pace of living resulting from studying extra-curricular activities as well as special sensitivity to media, which often promote false or incomplete information about nutrition. Abnormal consumption of food, low variety of foods and dishes, low nutritional value (e.g. fast foods, cakes, sweet drinks), and also insufficient intake of cereal products with grain, fish, vegetables and fruits are the most common issues of school age (Szczepańska et al., 2014).

Globally, malnutrition is a major public health problem among school age children. More than 200 million school age children are stunted and underweight and if no action is done at this rate, about one billion school children will suffer from impaired physical and mental development by 2020 (Ara et al., 2011 \& Srivastava et al., 
2012). In developing countries, malnutrition is the primary cause of illness and premature mortality among children (ALI, 2012).

Malnutrition can be caused by many factors as; inappropriate food intake, infections, psychosocial deprivation, insanitary environment, lack of hygiene, social inequality and possibly some genetic contribution as well. Reports from different organizations like the World Bank documented that, children who live in households deficient in clean, healthy food are more likely to predispose to health related problems than children from food secure households (Bhargava et al., 2015).

Adequate nutrition is a cornerstone of health and essential in early childhood to ensure healthy growth, proper organ formation and function, a strong immune system, neurological and cognitive development. Economic growth and human development require well-nourished populations who can learn new skills, think critically and contribute to their communities (Report of the Dietary Guidelines Advisory Committee, 2010 \& CDC, 2015).

In Egypt, school children represent over $20 \%$ of the total population. In the city of Fayoum elementary school learners form about $39.8 \%$ of the total number of students (El-zanaty and Away, 2010). National Association of School Nurses (2013) reported that children are in need of health education regarding nutrition and health promotion. The nutritional status of school-going children affects their health, cognition, and then their educational performance. The school is a suitable environment for providing health and nutrition services to disadvantaged children (Best et al., 2010).

Sharma, Gernand, and Day (2008) concluded during childhood there is a need to create healthy dishes. Usually, a healthy food is not a priority for juveniles, and poor nutrition may present a danger for current and future health problems. American Dietetic Association (2010) reported that a large number of school-focused food program have been implemented globally, largely focusing on obesity, physical activity, and the importance of vegetables and fruits. Nevertheless, adolescent-based food has been published in very few studies. The importance of improving nutritional knowledge through food education should not be underestimated by having a positive impact on the choice of healthy food (Story et al., 2002).

\subsection{Significance of the Study}

Nutritional disorders affect more than $35 \%$ of school children in Egypt. Inadequate nutritional intake has important implication because malnutrition has been shown to negatively affect the cognitive development of primary school children, and affects children's interaction with school teachers and their ability to excel in their studies. The prevalence of child malnutrition in Egypt was 29 percent, which makes it one of the 36 high burden countries of the world (UNICEF, World Bank, WHO and United Nations DESA/Population Division, 2011).

\subsection{The Study Aim}

The study aimed to assess the dietary habits and nutritional knowledge among students in the primary school in Fayoum Governorate, Egypt.

\subsection{Research Questions}

1. What are the dietary habits of the primary school students?

2. What is the knowledge of the student about nutrition?

3. What is the general appearance of the students?

4. Is there a relation between the students' nutritional status and their educational performance?

5. Is there a relation between gender and the student nutritional status?

\section{Materials and Methods}

\subsection{Research Design}

Cross-sectional survey was utilized.

\subsection{Setting}

The study was carried out at three governmental morning mixed primary schools in Fayoum city, Egypt. These schools were selected randomly namely as: Molhaket El-Moalemeen, Keman-fars, and EL-Sofey. The total students in the three schools were 1760 distributed as follows: Molhaket El-Moalemeen primary school 547, Keman-Fares 520, and EL-Sofey primary school 693 students from age 10-12 years. 


\subsection{Subject}

A cluster random sample was obtained from entire governmental mixed primary schools in Fayoum city, Egypt, including children aged from 10-12 year and free from any psychiatric or physical disorder, chronic diseases and accepts to participate in the study.

\subsection{Technique}

Two educational sectors at El -Fayoum city were located in the Eastern and Western sites. A list of the governmental mixed primary schools in one sector (Western) was obtained from the Ministry of Education. The cluster sampling divided into three stages. First stage; total number of primary schools was 12 and three schools were chosen randomly. Second stage one class selected from grade five and another one from grade six. The third stage was the selection of a classroom in this stage, the list of classrooms at grade five and six in each school was listed in slips paper and randomly selected.

\subsection{Sample Size}

Sample size was calculated using openEpi based on the following assumptions: significance Level 0.05 , power of the study $90 \%, 5 \%$ margin of error, the proportion of good knowledge based on previous research $30 \%$. The estimated sample size was 300 .

\subsection{Tools of Data Collection}

Three tools were employed based on the related literature.

First tool: self-administered questionnaire developed by the investigators consisted of two parts: Part I: Socio-demographic data of school children as age, gender, previous school performance, family income, parent's education and occupation. Part II: consisted of the student knowledge about nutrition composed of 21close-ended questions about the components of healthy food, sources and the importance of protein, vitamins, carbohydrates, fats, and the importance of nutrition for health. Scoring of students' knowledge is marked as a point to each correct answer and each wrong answer as zero. Items score summarized and grouped into three levels as follows: Good; $75 \%$ or more (score: $15.75-21$ ), Fair; $50 \%-<75 \%$ (score $10.5-<15.75$ ) and Poor; $<$ $50 \%$ (score $0-<10.5$ ).

Second tool: self-administered questionnaire to assess dietary habits of the students. This part composed of 16 close- ended questions answered as "yes" or "no" as eating breakfast daily, drinking water, milk, eating three meals/day, taking sandwiches to school, drinking tea immediately after meals, drinking water while eating and prefer eating nuts. Scoring system of student's habits, for each "yes" answer one point was given to summarize the maximum score of 16 points. Items categorized as healthy habits; $\geq 50 \%$ and bad habits; $<50 \%$.

Third tool: student health assessment sheet it covered 2 parts: part I. Anthropometric measurement of the students (weight, height, BMI). The weight was measured to an accuracy of $0.1 \mathrm{~kg}$ by electronic scale; the children worn light weight clothing and no shoes. The height of the child should be measured to the nearest 0.1 $\mathrm{cm}$ using a wooden stadiometer placed on a flat surface. Weight, height, and age data were used to calculate the z-points of the three different nutritional indicators compared to the World Health Organization (WHO) reference population using the WHO AnthroPlus software (version 10.4), 2010). These indicators are:

(1) Height - for-age z-score (HAZ) (age range: 5-19 years) to measure stunting that defined as (HAZ) $<-2 \mathrm{SD}$ (WHO, 2016).

(2) Weight-for-age z-score (WAZ) (age range: 5-10 years) to assess if the child was underweight up to 10 years old. After 10 years of age, weight-for-age was not a good indicator where the children grow faster during the period of puberty and can be falsely categorized as excess weight. Underweight was defined as (WAZ) $<-2 \mathrm{SD}$ (Blössner et al., 2010).

(3) BMI measured weight in kilograms divided by height in meters squared. BMI-for-age weight status categories and the related interest were based on the recommendations of the committee of experts and submitted as reduced body weight less than the 5th percentile, normal or healthy weight 5 th percentile to less than the 85th percentile, overweight 85 th to less than 95th percentile and obesity equal to or over the 95th percentile (CDC, 2018).

Part II. Assessment of the student's appearance as regards hair, face, nails, lips, tongue, gums, teeth, and skin and were categorized as healthy appearance if $\geq 50 \%$ of maximum score or unhealthy appearance if $<50 \%$. 


\subsection{Validity \& Reliability of the Tool}

Content validity of the tool was tested by 5 faculty experts in the public health department in medical college and nursing colleges from the community health department.

Reliability of the tools was assessed using coefficient alpha (0.73).

\subsection{Pilot Study}

A pilot study was conducted on $10 \%$ (30) students for the clearance and the accuracy of the instrument, and they were excluded from the study. Accordingly, minor changes had been made.

\subsection{Field Work}

Permission to conduct the study was obtained from the directors of the school. The data collection procedure continued from October to March 2016. It took about half an hour to fill out all the forms of each student. For data collection the researcher introduced herself and explained the study purpose.

\subsection{Ethical Considerations}

Written informed consent included a simple explanation of the purpose and nature of the study sent with each pupil to be signed by the parent / guardian. The researcher emphasized that participation in this study was entirely voluntary, that anonymity and confidentiality were ensured by encoding the data and they were informed of their rights to opt-out or to withdraw at any time.

\subsection{Statistical Analysis}

The statistical analysis of the data was carried out using the SPSS version 16.0. Data were described in the form of mean, frequency and proportion of quality data. Z-points of $(<-2 \mathrm{SD})$ were calculated to illustrate WAZ, HAZ underweight and stunting. The analysis of the data was made to verify the statistically significant difference between knowledge and academic achievement. Chi- square and a Pearson coefficient were used. The value of $\mathrm{P}$ $\leq 0.05$ was statistically significant.

\section{Results}

Table 1. Distribution of the students in relation to their socio-demographic data $(n=300)$

\begin{tabular}{lll}
\hline Items & N. & \% \\
\hline Age & 59 & 19.6 \\
$\leq 10$ & 92 & 30.7 \\
11 & 149 & 49.7 \\
\cline { 2 - 3 } 12 & $\mathbf{1 1 . 2 7 \pm 0 . 9 2 8}$ & \\
Mean \pm SD & & \\
\hline Sex & 96 & 32.0 \\
Boy & 204 & 68.0 \\
Girl & & \\
\hline Number of brothers & 135 & 45.0 \\
$0-<3$ & 165 & 55.0 \\
$\geq 3$ & & \\
\hline Child order & 89 & 29.7 \\
First & 135 & 45.0 \\
Middle & 76 & 25.3 \\
Last & & \\
\hline Last year's school performance & & 38.0 \\
Excellent & 114 & 35.7 \\
Very good & 107 & 26.3 \\
Good & 79 & \\
\hline
\end{tabular}




\begin{tabular}{lll}
\hline Father Education & 3 & 1.0 \\
Illiterate & 202 & 67.3 \\
intermediate & 95 & 31.7 \\
High & 293 & 97.7 \\
\hline Father occupation & 7 & 2.3 \\
Working & & \\
Not working & 9 & 3.0 \\
\hline Mother education & 206 & 68.7 \\
Illiterate & 85 & 28.3 \\
intermediate & \\
High & 83 & 27.7 \\
\hline Mother occupation & 217 & 72.3 \\
Working & & \\
House wife & 135 & 45.0 \\
\hline Residence & 165 & 55.0 \\
Rural & & 25.0 \\
Urban & 75 & 75.0 \\
\hline Family monthly income & 225 & \\
Adequate & & \\
Inadequate & & \\
\hline
\end{tabular}

Table 1 shows that, around half (49.7\%) of the students are aged from 12 years with a mean age $11.27 \pm 0.928$ years. Almost two-third (68.0\%) were female while more than half (55\%) had 3 brothers. As regards to the order of the child less than half $(45 \%)$ were in the middle. More than one-third $(38 \%, 35.7 \%)$ had excellent and very good school performance last year respectively. For parents occupation, the most (97.7\%) of the fathers were working while nearly three-fourth $(72.3 \%)$ of the mothers were housewives. For father and mother education two-third $(67.3 \%, 68.7 \%)$ was intermediate education respectively. More than half $(55 \%)$ were from urban and three-fourth (75\%) had inadequate income.

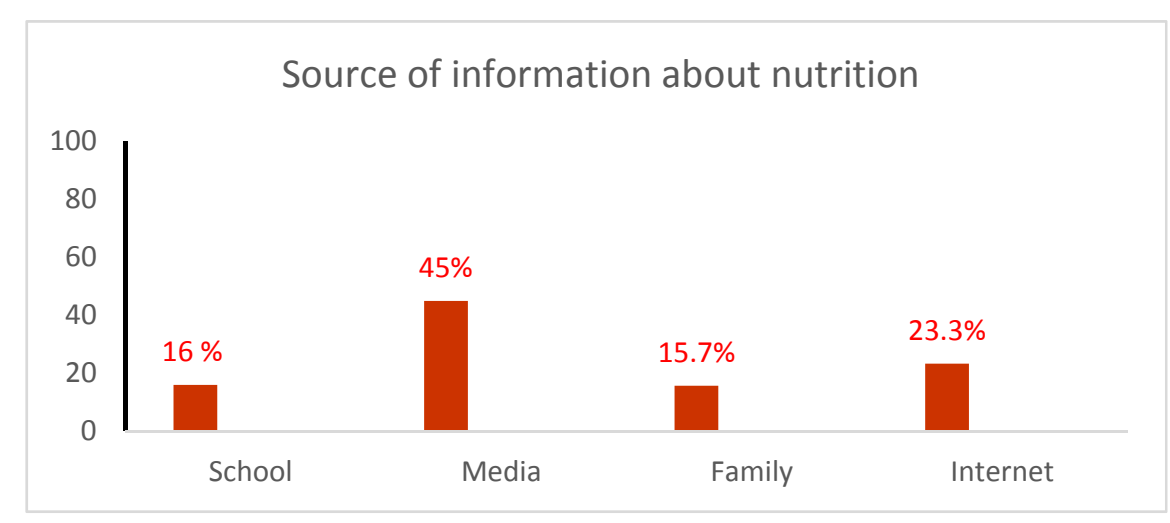

Figure 1. Distribution of the students according to their source of information about nutrition $(n=300)$

Figure 1 represents the source of information about nutrition among the study group, less than half (45\%) TV was the source of information while around a quarter $(23.3 \%)$ internet while the minority $(16.0 \%, 15.7 \%)$ the school and family respectively were the source of information about nutrition. 


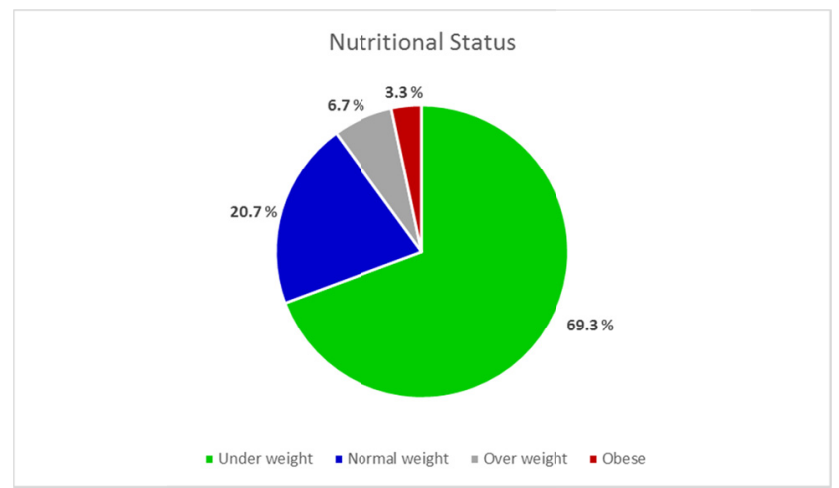

Figure 2. Distribution of the students according to their nutritional status based on Weight-for-age indicator and Body Mass Index $(n=300)$

Figure 2 shows that in relation to weight-for-age indicator, more than two third (69.3\%) of the students were underweight while around one-fifth (20.7\%) were normal weight and the minority $(6.7 \%),(3.3 \%)$ were overweight and obese respectively.

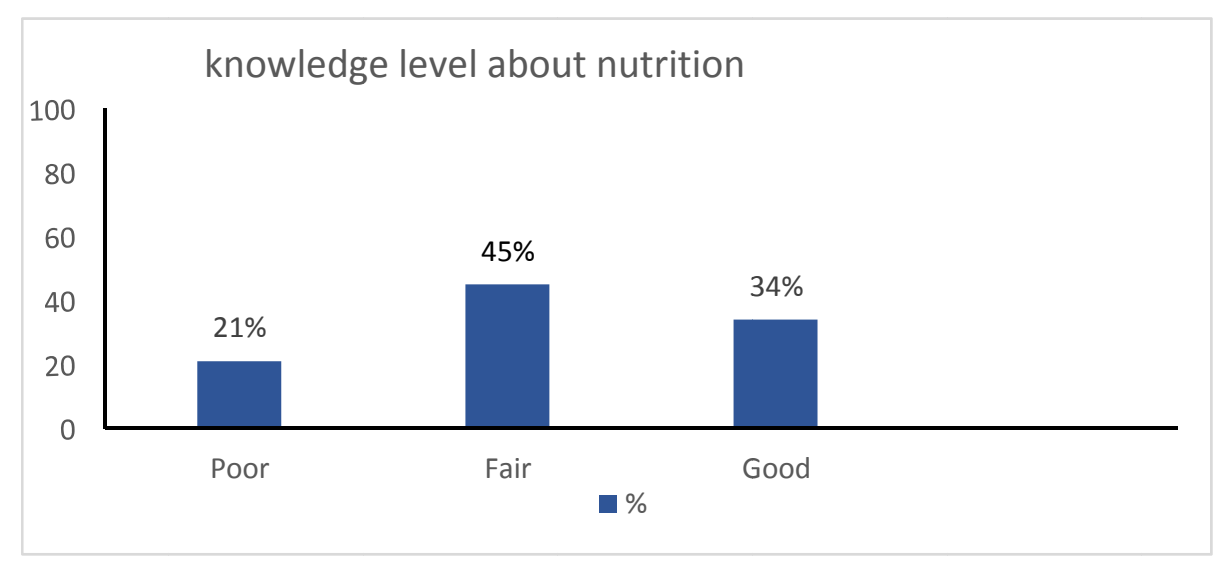

Figure 3. Distribution of the students in relation to their knowledge level about nutrition $(n=300)$

Figure 3 illustrates that in relation to knowledge level about the nutrition among the students, less than half (45\%) had fair knowledge while one-third (34\%) had good knowledge and one fifth (21\%) had poor knowledge about the nutrition.

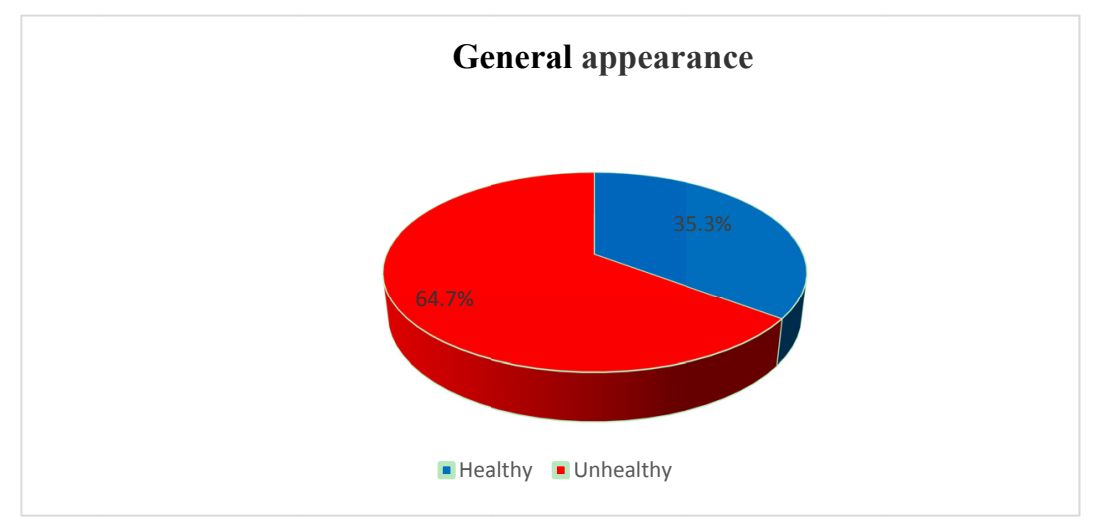

Figure 4. Distribution of the students according to their general appearance $(n=300)$ 
Figure 4 shows that in relation to the general appearance of the students, more than one-third $(35.3 \%)$ had healthy appearance while more than half $(64.7 \%)$ of the students had unhealthy appearance.

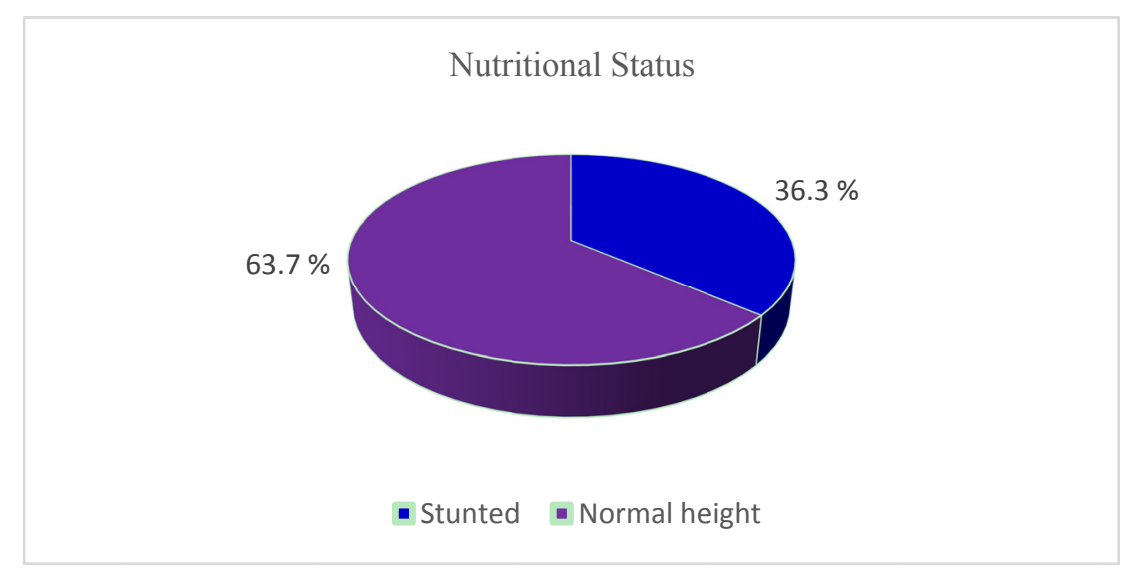

Figure 5. Distribution of the students according to their nutritional status based on Height for age indicator ( $\mathrm{n}=$ 300)

Figure 5 clarifies the nutritional status based on height for age indicators, around two-third (63.7\%) of the students were normal height while more than one-third $(36.3 \%)$ of them were stunted.

Table 2. Distribution of the students in relation to their dietary habits $(n=300)$

\begin{tabular}{|c|c|c|c|c|}
\hline \multirow[t]{2}{*}{ Items } & \multicolumn{2}{|l|}{ Yes } & \multicolumn{2}{|l|}{ No } \\
\hline & $\mathbf{N}$. & $\%$ & $\mathbf{N}$. & $\%$ \\
\hline Eating breakfast daily & 60 & 20.0 & 240 & 80.0 \\
\hline Drinking milk regularly & 6 & 2.0 & 294 & 98.0 \\
\hline Eating three meals/day regularly & 61 & 20.3 & 239 & 79.7 \\
\hline Taking snacks between meals & 85 & 28.3 & 215 & 71.7 \\
\hline Taking sandwiches to school & 249 & 83.0 & 51 & 17.0 \\
\hline Food handlers present around the school & 285 & 95.0 & 15 & 5.0 \\
\hline Buy food from handlers & 271 & 90.3 & 29 & 9.7 \\
\hline Drinking tea immediately after meals & 114 & 38.0 & 186 & 62.0 \\
\hline Drinking water while eating & 272 & 90.7 & 28 & 9.3 \\
\hline Prefer eating nuts & 210 & 70.0 & 90 & 30.0 \\
\hline drink too much gaseous water throughout the day & 108 & 36.0 & 192 & 64.0 \\
\hline Eating too much sweets & 242 & 80.7 & 58 & 19.3 \\
\hline Like to eat spicy food & 150 & 50.0 & 150 & 50.0 \\
\hline Prefer to eat vegetables $\&$ fruits & 223 & 74.3 & 77 & 25.7 \\
\hline Eating while watching TV & 184 & 61.3 & 116 & 38.7 \\
\hline Eating too much during exposure to stress & 261 & 87.0 & 39 & 13.0 \\
\hline
\end{tabular}

Table 2 illustrates that in relation to the nutritional habits of the students, most $(80 \%),(98 \%)$ of them did not take their breakfast and also did not regularly drink milk respectively. More than one-fifth (20.3\%), (28.3\%) eating 3 meals /day and taking snacks between meals respectively. Most of the students (83\%) taking sandwiches to school. Most of the school (95\%), (90.3\%) food handlers present around it and the students bought food from handlers respectively. As regards drinking of water and tea, most of them $(90.7 \%)$ drunk water during eating while more than one-third (38\%), (36\%) drunk tea immediately after meals and also drunk too much gaseous 
water respectively. For eating nuts, sweats and vegetables and fruits, more than two-third (70\%), (80.7\%), $(74.3 \%)$ ate it respectively. More than half $(61.3 \%)$ ate while watching the TV and most $(87 \%)$ of them ate more during stress.

Table 3. Relation between academic performance and nutritional indicators of the study group ( $\mathrm{n}=300)$

\begin{tabular}{|c|c|c|c|c|c|c|}
\hline \multicolumn{3}{|c|}{ Nutritional indicators } & \multicolumn{3}{|c|}{ Academic performance } & \multirow{2}{*}{$\begin{array}{l}\mathrm{X}^{2} \\
\text { P value }\end{array}$} \\
\hline & & & Excellent & Very good & Good & \\
\hline \multirow[t]{4}{*}{ HAZ } & Normal & $\mathbf{N}$. & 85 & 62 & 44 & \multirow{4}{*}{$\begin{array}{l}18.24 \\
\leq 0.05^{*}\end{array}$} \\
\hline & & $\%$ & 74.6 & 57.9 & 60.3 & \\
\hline & \multirow[t]{2}{*}{ Stunted } & N. & 29 & 45 & 29 & \\
\hline & & $\%$ & 25.4 & 42.1 & 39.7 & \\
\hline \multirow[t]{6}{*}{$\overline{\text { WAZ }}$} & Normal & N. & 97 & 91 & 53 & \multirow{6}{*}{$\begin{array}{l}7.6 \\
>0.0 .5\end{array}$} \\
\hline & & $\%$ & 85.1 & 85.0 & 72.6 & \\
\hline & Overweight & N. & 8 & 8 & 8 & \\
\hline & & $\%$ & 7.0 & 7.5 & 11.0 & \\
\hline & \multirow[t]{2}{*}{ Underweight } & N. & 9 & 8 & 12 & \\
\hline & & $\%$ & 7.9 & 7.5 & 16.4 & \\
\hline
\end{tabular}

Table 3 illuminates the relation between the study group academic performance and their nutritional indicators, there was a statistically significant difference $(\mathrm{P}: 0<0.05)$ between the students' academic performance and their HAZ. While, there was no statistically significant difference between the academic performance and their WAZ (P: 0.264).

Table 4. Relation between sex and nutritional indicators of the study group $(n=300)$

\begin{tabular}{|c|c|c|c|c|}
\hline \multirow[t]{4}{*}{ Nutritional indicators } & & \multicolumn{2}{|l|}{ Sex } & \multirow{4}{*}{$\begin{array}{l}X^{2} \\
P \text { value }\end{array}$} \\
\hline & & Male & Female & \\
\hline & & $\mathbf{N}$ & $\mathbf{N}$ & \\
\hline & & $\%$ & $\%$ & \\
\hline \multirow[t]{4}{*}{ Height-for-age (HAZ) } & \multirow[t]{2}{*}{ Normal } & 50 & 141 & \multirow{4}{*}{$\begin{array}{l}-8.18 \\
\leq 0.05^{*}\end{array}$} \\
\hline & & 52.1 & 69.1 & \\
\hline & \multirow[t]{2}{*}{ Stunted } & 46 & 63 & \\
\hline & & 47.9 & 30.9 & \\
\hline \multirow[t]{6}{*}{ Weight-for-age (WAZ) } & Normal & 74 & 173 & \multirow{6}{*}{$\begin{array}{l}2.67 \\
->0.05\end{array}$} \\
\hline & & 77.1 & 84.8 & \\
\hline & \multirow[t]{2}{*}{ Overweight } & 10 & 14 & \\
\hline & & 10.4 & 6.9 & \\
\hline & \multirow[t]{2}{*}{ Underweight } & 12 & 17 & \\
\hline & & 12.5 & 8.3 & \\
\hline
\end{tabular}

Table 4 illuminates the relation between gender of the study group and their nutritional indicators, there was a statistically significant difference (P: 0.004) between gender of the students and their height. For WAZ, the minority of girls and boys $(6.9 \%),(8.3 \%),(10.4 \%),(12.5 \%)$ had overweight and underweight respectively with no statistically significant difference between WAZ and gender (P: 0.262). 
Table 5. Relation between the study group knowledge level, nutritional habit and general appearance $(n=300)$

\begin{tabular}{|c|c|c|c|c|c|c|}
\hline \multirow[t]{2}{*}{ Items } & \multicolumn{5}{|c|}{ Knowledge level } & \multirow{2}{*}{$\begin{array}{l}X^{2} \\
P \text { value }\end{array}$} \\
\hline & & & Poor & Fair & Good & \\
\hline \multirow[t]{4}{*}{ Nutritional Habits } & Healthy & $\mathrm{N}$. & 24 & 40 & 32 & \multirow{4}{*}{$\begin{array}{l}1.4427 \\
->0.05\end{array}$} \\
\hline & & $\%$ & 25.0 & 41.7 & 33.3 & \\
\hline & Unhealthy & $\mathrm{N}$. & 39 & 95 & 70 & \\
\hline & & $\%$ & 19.1 & 46.6 & 34.3 & \\
\hline \multirow[t]{4}{*}{ General Appearance } & Healthy & $\mathrm{N}$. & 39 & 89 & 52 & \multirow{4}{*}{$\begin{array}{l}5.5281 \\
>0.05\end{array}$} \\
\hline & & $\%$ & 21.7 & 49.4 & 28.9 & \\
\hline & Unhealthy & $\mathrm{N}$. & 24 & 46 & 50 & \\
\hline & & $\%$ & 20.0 & 38.3 & 41.7 & \\
\hline
\end{tabular}

Table 5 shows the relation between the study group knowledge level, nutritional habit and general appearance, in relation to the nutritional habits and the knowledge level among the healthy nutritional habits one-third (33.3\%) had good knowledge with no statistically significant difference. As regards relation between appearance and knowledge level, among the healthy appearance (49.4\%) had fair level of knowledge while $(20 \%)$ of the unhealthy had poor level of knowledge with no statistically significant difference.

Table 6. Correlation between the study group knowledge score, nutritional habit and general appearance $(\mathrm{n}=$ 300)

\begin{tabular}{lllc}
\hline & & Nutritional habits & Appearance \\
\hline \multirow{2}{*}{ Knowledge Score } & $\mathrm{R}$ & 0.054 & 0.080 \\
\cline { 2 - 4 } & P-value & 0.349 & 0.168 \\
\hline
\end{tabular}

Table 6 shows that there was a positive correlation between the study group knowledge, nutritional habit and general appearance with no statistically significant difference.

\section{Discussion}

WHO (2013) reported that school age children constitute a significant and important sector of the population that is constantly growing. Good children's health, attendance and educational performance can be promoted. Food and Agriculture Organization (2014) concluded nutritional wellbeing is influenced by the nutritional value of foods consumed in relation to age, sex, level of physical activity and health status requirements, as well as the efficiency of nutrient utilization by the body. Appropriate dietary intake is essential for the formation of good eating habits and provides the needed nutrients for growth, long-term health, cognition and children's school performance. Malnutrition is highly common among children in low and middle income countries. However, there are wide variations in the overall prevalence of underweight, stunting and child wastage across countries (Abdelaziz, Labib and Sedrak, 2015).

The present study was aimed to assess the dietary habits and nutritional knowledge among primary school children at Fayoum Governorate. According to the socio-demographic characteristics of primary school children, the present study findings revealed that, around half of the school students aged 12 years with mean age 11.27 .928, almost two third were female. These results were supported with Ali, Habib, and Ismail (2016) conducted a study to assess nutritional status among primary governmental school students, Cairo Governorate, Egypt and found that nearly half of school students were 11 years, while slightly more than one quarter were 12 years with a mean age $11.44 \pm 89.4$ years and more than half of the students were female.

According to parent's education, the present study findings revealed that, two third of father and mother had intermediate education respectively; the majority of the fathers were working, while nearly three-fourth of the mothers was housewives. This finding was in agreement with Ali, Habib, and Ismail (2016) who found that the majority of fathers were working and almost two third of the student's mothers were housewives, while slightly 
more than one quarter were working. It is my point of view that there are many factors can affect the student academic performance as economic factors, the level of education of the mother and the father not only eating patterns.

In relation to the study group source of information about nutrition, the present study findings revealed that, TV was the source of information among less than half followed by internet around quarter while the minority was school and family respectively. This findings was disagreed with Abbas et al., (2015) conducted a study to assess the relation between nutritional health status and learning performance among primary school children in Sonover Village ,Fayoum , Egypt and found that the most students common source of nutrition gaining from school $(61.6 \%)$, followed by readings $(40.8 \%)$. While the low source from the dish programs. On the same line Partida et al., (2018) found that, the Middle school students reported wanting to receive this nutrition information through coaches most often, while high school students reported wanting nutrition education through information sheets and the internet.

Regarding to nutritional status of school children, the present study findings, showed that more than two third were underweight, while more than one third were stunted and around one fifth were normal weight. These could be as a result of poor socio-economic status of the study sample. This finding was in accordance with Hassan, Abdelwahed and Eldessouki (2018) did a study to assess nutritional status and some socio-demographic and lifestyle characteristics among a group of rural school children in Fayoum Governorate, Egypt and found that , the prevalence of stunting, underweight and wasting among school children in Fayoum was high; (34.2\%),(3.4\%) and $(0.9 \%)$ respectively. On the contrary Abdelaziz, Labib, and Sedrak (2015) reported that in a survey conducted earlier in Beni-Suef Governorate, the prevalence of the underweight and stunted was (10\%) and $(53.2 \%)$ respectively. This difference may be due to the fact that the population studied included both urban and rural areas with poorer socio demographic characteristics. On the same line Sarma et al., (2013) reported that the male children had a 30\% higher chance of being underweight, $60 \%$ more likely to be stunted and $40 \%$ more likely to be thin than female.

According to knowledge score level about the nutrition, the current study findings shown that, less than half of school children had fair knowledge while one-third had good knowledge, and one fifth had poor knowledge score. This can be explained by the ineffectiveness of health education programs for nutrition by the school health team. This finding coincides with Nichols, Francis, and Dalrymple (2014) conducted a study in Trinidad and Tobago, found that a low level of dietary knowledge among primary school children. In the same stream Al-Yateem and Rossiter (2017) who evaluated the nutritional knowledge and habits of adolescents aged 9 to 13 in Sharjah, United Arab Emirates and reported that most students $(86 \%)$ had poor nutritional knowledge, especially in key areas: what are healthy snacks and foods, daily dietary requirements and food components (for example, fiber, fat, and sugar).

Concerning to nutritional habits, the present study findings revealed that, the most school children did not take their breakfast also did not drink milk while more than one-fifth eating three meals /day and taking snacks between meals. Also, most of school children taking sandwiches to school. This is due to several reasons, such as a lack of time in the morning and hurry to go school as well as not being hungry, in addition to have no appetite and low socio-economic level. This finding was in agreement with the study conducted by Mohamed and Farg (2016) who found that more than half of school children skipped breakfast before going to school, Also Abudayya et al., (2011) conducted a study in Gaza reported that school children did not prefer to eat the bread done at home in the breakfast, but they preferred to take money and buy sandwiches from food handlers around the school.

Regarding drinking of water and tea, most of school children drunk water during eating while more than one-third drunk tea immediately after meals and also drunk too much gaseous water. This could be explained that students in the present study were from urban areas still they might have family roots from rural and Upper Egypt where drinking tea immediately after eating is tradition in these areas. This finding at the same line with Ali, Habib, and Ismail (2016), who found that slightly more than three quarter of the students were drinking tea immediately after eating. Also Abdel hady, El-Gilany, and Sarraf (2014) assessed dietary habits of school students on 927 students in Mansoura-Egypt and reported that more than three quarter of the students were drinking tea immediately after eating. In Egypt, it is expected to drink tea immediately after eating especially in rural and Upper Egypt communities.

As for eating nuts, sweat, vegetables and fruits, the results of this study revealed that more than two-thirds of the students ate it and more than half of them ate while watching TV. This finding was consistent with Abdel hady, El-Gilany, and Sarraf (2014) found about (80\%) and (29\%) of students reported daily consumption of vegetables 
and fruits, respectively. While in contrast with Mahfouz et al., (2011) did a study of eating behavior in Liverpool showed that, only $21 \%$ of secondary school children regularly ate fruits and vegetables. Another study carried out by Turconi et al., (2008) who assessed the eating habits and behaviors, physical activity, food and nutritional safety and beliefs in an adolescent Italian population and found that consumption of sweets and cakes is too high in about $25 \%$ of the sample, in that a dessert or cake is always consumed at each meal.

According to school performance of students in the last year, the present study findings revealed that, more than one third of school children had an excellent and very good respectively. This finding was incongruent with Mohamed and Farg (2016) who found that more than two thirds of boys and girls had average level scholastic achievement. Similar to Lee and Manan (2014) who studied malnutrition status and academic performance among primary school children in Malaysia and found that, most students was average school performance.

Regarding the relation between academic performance and nutritional indicators, the current study indicated that, there was a statistically significant difference $(\mathrm{P}: 0<0.00)$ between the academic performance of the students and their HAZ. While, there was no statistically significant difference between the academic performance of the students and their WAZ (P: 0.264). This finding supported with Sarma et al., (2013) who reported that the low level of educational attainment (estimated $<40 \%$ ) for Tamil (Language), Mathematics and overall subject average were higher among underweight and stunted children than the normal children. On the other hand, A study in East of Uganda carried out by Acham et al., (2008) who found that all nutritional indicators (HAZ, WAZ and BMI) had significant positive associations with learning achievement in English (Language) and mathematics in 4th grade children.

Concerning the relation between sex and nutritional indicators, the present study findings revealed that, there was a statistically significant difference between gender of the students and their height. For WAZ, the minority of girls and boys $(6.9 \%),(8.3 \%),(10.4 \%),(12.5 \%)$ had overweight and underweight respectively with no statistically significant difference between WAZ and gender. This finding was incongruent with Sarma et al., (2013) who have found that male children are $30 \%$ more likely to be underweight, with $60 \%$ more chance of being stunted and $40 \%$ more likely to be thinner than the female children. Also, Mian, Ali, Ferroni, and Underwood, (2002) reported that, there is no link between nutritional status and gender among school students in Pakistan.

As regards the relation between the studied subjects' knowledge level, nutritional habits and general appearance, the present study findings showed that one third of school children had good knowledge in relation to the nutritional habits and their knowledge level with no statistically significant difference. These results were supported by Partida et al., (2018) who found that the connection between nutritional knowledge and dietary habits indicate that there are many more factors besides nutrition knowledge that impact dietary habits.

The current study revealed that, a positive correlation between the studied subjects knowledge, nutritional habit and general appearance with no statistically significant difference. These findings were in agreement with Al-Yateem and Rossiter (2017) reported that a positive association between higher levels of nutritional knowledge and healthier eating habits, including eating more fruit and vegetables, eating more regularly at breakfast and consuming less unhealthy snacks and less fast food.

\section{Conclusion}

Underweight is highly prevalent among the primary school students followed by stunting. Most of the students had unhealthy appearance while around half of them had fair knowledge about nutrition. There were a positive correlation between the dietary knowledge, nutritional habit and general appearance of the school age students with no statistically significant difference while there were a statistically significant difference (P: 0.004) between gender of the students and height-for-age indicator.

As regards to the dietary habits, excess consumption of spicy foods, sugar/sweets, did not eat breakfast and also did not drink milk were the main unhealthy eating behavior among the school age students while prefer to eat vegetables and fruits, did not drink tea immediately after meals were the healthy eating behavior among the study group.

\section{Recommendation}

Maximizing the health potential of school age requires a sustainable and organized action programs, involving: school health education, health promotion programs targeted at parents and adolescent organizations in the community, in addition to national initiatives with more emphasis on nutrition and healthy diet. 


\section{References}

Abbas, S., El-Badway, A., Wafik, W., \& Al adham, N. (2015). Relation between health and nutritional status and learning performance among primary school children in Sonover district, Fayoum governorate. Doctorate Thesis, Zagazig University.

Abdel Hady, D., El-Gilany, A., \& Sarraf, B. (2014). Dietary habits of school students. International Journal of Collaborative Research on Internal Medicine and Public Health, 6(6), 132-44.

Abdelaziz, S. B., Labib, M. R., \& Sedrak, A. S. (2015). Nutritional Status and Dietary Habits of School Children in Beni-Suef Governorate, Egypt. Food and Nutrition Sciences, 6, 54-63.

Abudayya, A., Shi, Z., Abed, Y., \& Holmboe Ottesen, G. (2011). Diet, nutritional status and school performance among adolescents in Gaza Strip. EMHJ, 17(3), 218-25.

Acham, H., Kikafunda, J. K., Oluka, S., Malde, M. K., \& Tylleskar, T. (2008). Height, weight, body mass index and learning achievement in Kumi district, East of Uganda. Scientific Research and Essay, 3(1), 1-8.

Ali, M. (2012). Assessment of the nutritional status serum iron and zinc level in children short stature (pp. 4-5). Master thesis.

Ali, S. G., Habib, S. N., \& Ismail, M. G. (2016, March). Nutritional Status among Primary Governmental School Student's. Cairo Governorate Med. J. Cairo Univ., 84(1), 157-165. Retrieved from www.medicaljournalofcairouniversity.net

Al-Yateem, N., \& Rossiter, R. (2017). Nutritional knowledge and habits of adolescents aged 9 to 13 years in Sharjah, United Arab Emirates: a cross-sectional study. EMHJ, 23(8), 551-58.

American Dietetic Association. (2010). Position of the American Dietetic Association: child and adolescent nutrition assistance programs. $A D A, 110(5), 791-9$.

Ara, R., Huque, S. R., Adhikary, M., Uddi, M. N., Mahmood, A. R., et al. (2011). Nutritional status among primary school children in a selected rural community. J. Dhaka Med. Coll, 20, 97-101.

Best, C., Neufingerl, N., Van Geel, L., Van Denbriel, T., \& Osendarp, S. (2010). The nutritional status of school-aged children: Why should we care?. Food and Nutrition Bulletin, 31(3), 400-17.

Bhargava, M., Aggarwal, P., Kandpal, S. D., \& Semwal, J. (2015). Magnitude of Under nutrition in Urban and Rural Schoolgoing children of District Dehradun using WHO Reference. Standards Ntl J of Community Med, 6(4), 452-457.

Blössner, M., Siyam, A., Borghi, E., et al. (2010). WHO AnthroPlus Software. WHO, Department of Nutrition for Health and development, Geneva. Retrieved from http://www.who.int/childgrowth/software /anthro_pc_manual.pdf

Centers for Disease Control and Prevention (CDC). (2015). Nutrition and the Health of Young People. Retrieved from http://www.cdc.gov/healthyschools/nutrition/facts.htm

Center for Disease Control and Prevention (CDC). (2018). Healthy weight. About child and teen BMI. Division of Nutrition, Physical Activity and Obesity. National Center for Chronic Disease Prevention \& Health Promotion.

El-zanaty, F., \& Away, A. (2010). Egypt Demographic and Health Survey. EDHS Calverton, Maryland USA, National Population Council and ORC Marco.

Food and Agriculture Organization. (2014). International conference on Nutrition. Food and Agriculture Organization of the United Nations. International Year of Soils. Retrieved 5 January 2015, from http://www.fao.org/ partnerships/strategies/en

Hassan, K. S., Abdelwahed, Y. W., \& Eldessouki, R. (2018). Nutritional Status and Some Sociodemographic and Lifestyle Characteristics among A Group of Rural School Children in Fayoum. The Egyptian Journal of Community Medicine, 36(2), 1-11.

Lee, Y., \& Manan, W. A. (2014). Nutritional status, academic performance and parental feeding practices of primary school children in a rural district in Kelantan, Malaysia. Progress in Health Sciences, 4(1), 144.

Mahfouz, A. A., Shatoor, A. S., Khan, M. Y., Daffalla, A. A., Mostafa, O. A., \& Hassanein, M. A. (2011). Nutrition, physical activity, and gender risks for adolescent obesity in Southwestern Saudi Arabia Saudi. $J$ Gastroenterol, 17(5), 318-22. 
Mian, R. M. A., Ali, M., Ferroni, P. A., \& Underwood, P. (2002). The nutritional status of school-aged children in an urban squatter settlement in Pakistan. Pakistan Journal of Nutrition, 1(3), 121-23.

Mohamed Al, H., \& Farg, K. H. (2016, May-August). Effect of Eating Pattern on Scholastic Achievement among Primary School Children in Anshas El-Raml Villag. Noverlty Journals, 3(2), 177-184. Retrieved from www.noveltyjournals.com

National Association of School Nurses. (2013). Definition of school nursing. Castle Rock, CO. Retrieved from www.nasn.org

Nichols, S. D., Francis, M. P., \& Dalrymple, N. (2014). Sustainability of a Curriculum-based Intervention on Dietary Behaviours and Physical Activity among Primary School Children in Trinidad and Tobago. West Indian Med J., 63(1), 68-77.

Partida, S., Marshall, A., Henry, R., Townsend, J., \& Toy, A. (2018). Attitudes toward Nutrition and Dietary Habits and Effectiveness of Nutrition Education in Active Adolescents in a Private School Setting: A Pilot Study. Nutrients, 10(1260).

Report of the Dietary Guidelines Advisory Committee. (2010). On the Dietary Guidelines for Americans, to the Secretary of Agriculture and the Secretary of Health and Human Services. Washington, DC: U.S. Department of Agriculture.

Sarma, G. M. S., Wijesinghe, N. G., \& Sivananthawerl, T. (2013). The Effects of Nutritional Status on Educational Performance of Primary School Children in the Plantation Sector inNuwara Eliya Educational Zone. Tropical Agricultural Research, 24(3), 203-214.

Sharma, S. V., Gernand, A. D., \& Day, R. S. (2008). Nutrition knowledge predicts eating behaviour of all food groups except fruits and vegetables among adults in the Paso del Norte region: Que Sabrosa Vida. JNEB, 40(6), 361-8.

Srivastava, A., Mahmood, S. E., Srivastava, P. M., Shrotriya, V. P., \& Kumar, B. (2012). Nutritional status of school age children - A scenario of urban slums in India. Archives of Public Health, 70, 8.

Sitko, D., Wojtaś, M., Gronowska-Senger, A. (2012). Food patterns of youth from gymnasium and lyceum. Rocz Panstw Zakl Hig 20Sitko D., Wojtaś M., Gronowska-Senger A.: Food patterns of youth from gymnasium and lyceum. Rocz Panstw Zakl Hig, 63(3), 319-327.

Story, M., Lytle, L. A., Birnbaum, A. S., \& Perry, C. L. (2002). Peer-led, school-based nutrition education for young adolescents: feasibility and process evaluation of the TEENS study. $J$ Sch Health, 72(3), 121-7.

Szczepańska, E., Szeja, N., Szymkiewicz, A., Kowalska, A., Lenard, B., \& Bulwicka, A. (2014). Eating behaviours of middle- and secondary-school pupils from the upper Silesian region in Poland. Rocz Panstw Zakl Hig, 65(4), 337-344.

Turconi, G., Guarcello, M., Maccarini, L., et al. (2008). Eating habits and behaviors, physical activity, nutritional and food safety and beliefs in an adolescent Italian population. $J$ Am Coll Nutr., 27(1), 31-43.

UNICEF, World Bank, WHO and United Nations DESA/Population Division. (2011). Levels and trends in child mortality report 2011: Estimates developed by an inter-agency group for child mortality estimation. Org/files/Child_Mortality_Report_2011. Retrieved February 22, 2015 from http://www.childinfo

World Health Organization (WHO). (2013). Anthrop us for personal computers. Manual Software for assessing growth of the world's children and adolescents 2009. Geneva. Retrieved from http://www.who.int/growthref/tools /en/

World Health Organization (WHO). (2016). Growth reference 5-19 years. Application tools: Anthroplus Software. Retrieved from bhttp://www.who.int/growthref/en/

\section{Copyrights}

Copyright for this article is retained by the author(s), with first publication rights granted to the journal.

This is an open-access article distributed under the terms and conditions of the Creative Commons Attribution license (http://creativecommons.org/licenses/by/4.0/). 